Available online at http://jurnal.goretanpena.com/index.php/JSSR

\title{
PENERAPAN DOMAIN MONITOR AND EVALUATE FRAMEWORK COBIT 4.1 DALAM PELAKSANAAN AUDIT SISTEM INFORMASI
}

\author{
Hambali \\ STMIK Royal, Kisaran \\ e-mail: hambali.160886@gmail.com
}

\begin{abstract}
The rapid development of information technology must of course be balanced with an audit of information systems to prevent such large losses. An audit was conducted to determine the security and data integrity of the information system used. The audit using the COBIT 4.1 framework, the domain used is Monitor and Evaluate (ME), due to the existing problems required for IT performance at the Department of Communication and Information, North Labuhan Batu Regency to be carried out optimally. Where the ME domain is direct supervision of the system in the form of internal control that is responsible for protecting organizational assets, preventing and finding losses if an error occurs. The purpose of this study is to determine the current maturity level and from the analysis carried out, it will produce recommendations. Based on the information system audit with monitoring and evaluation carried out, in general, the maturity condition of IT governance at Diskominfo Labura is currently at the defined process level. This level is obtained based on the results of interviews from several standard domains, namely ME1, ME2, ME3, and ME4 which have been processed to produce an average maturity level value of 2.84 with an expectation of level 4 and has a gap of 1.16 .
\end{abstract}

Keywords: Auditing, Cobit 4.1, IT Governance

\begin{abstract}
Abstrak: Berkembangnya teknologi informasi yang begitu pesat tentu harus diimbangi dengan audit terhadap sistem informasi guna mencegah kerugian yang begitu besar. Audit yang dilakukan untuk mengetahui keamanan dan integritas data dari sistem informasi yang digunakan. Audit menggunakan framework COBIT 4.1 domain yang digunakan adalah Monitor and Evaluate (ME), dikarenakan pada permasalahan yang ada dibutuhkan terhadap kinerja IT yang berada di Dinas Komunikasi dan Informatika Kabupaten Labuhan Batu Utara dapat dilakukan secara optimal. Dimana domain ME merupakan pengawasan langsung pada sistem berupa pengendalian internal yang bertanggung jawab melindungi asset organisasi, mencegah dan menemukan kerugian jika terjadi kesalahan. Tujuan penelitian ini adalah untuk mengetahui maturity level saat ini dan dari analisis yang dilakukan tersebut akan menghasilkan rekomendasi. Berdasarkan audit sistem informasi dengan monitoring dan evaluasi yang dilakukan secara garis besar kondisi kematangan tata kelola TI Diskominfo Labura saat ini berada tingkat defined process. Tingkat tersebut didapatkan berdasarkan hasil wawancara dari beberapa standar domain yaitu ME1, ME2, ME3, dan ME4 yang telah diolah dengan menghasilkan rata-rata nilai maturity level sebesar 2,84 dengan harapan level 4 dan memiliki gap sebanyak 1,16.
\end{abstract}

Kata kunci: Audit, Cobit 4.1, Tata Kelola TI

\section{PENDAHULUAN}

Peranan tata kelola teknologi informasi (TI) tidak lagi diragukan dalam mencapai tujuan organisasi yang berhubungan dengan sistem teknologi informasi. Seperti fungsi-fungsi manajemen lainnya pada organisasi publik, maka menghasilkan output yang optimal dalam organisasi, membantu proses pengambilan keputusan dan penyelesaian masalah. Pengelolaan TI 
Available online at http://jurnal.goretanpena.com/index.php/JSSR

merupakan proses untuk mengarahkan dan mengendalikan instansi dalam mencapai tujuan melalui peningkatan nilai dan tetap menjaga keseimbangan antara risiko dan manfaat dalam menerapkan TI.

Tujuan penelitian ini adalah untuk mengetahui maturity level saat ini dan dari analisis tersebut akan menghasilkan rekomendasi. Untuk mengevaluasi tata kelola teknologi informasi pada Diskominfo kabupaten Labura framework yang digunakan adalah COBIT (Control Objectives for Information and related Technology) 4.1 dengan fokus domain Monitor and Evaluate (ME).

COBIT adalah suatu panduan standar praktik manajemen teknologi informasi. Standar COBIT dikeluarkan oleh IT Governance Institute yang merupakan bagian dari ISACA. COBIT 4.1 memiliki 4 cakupan domain, yaitu domain Plan and Organise (PO), Acquire and Implemnt (AI), Delivery and Support (DS), dan Monitor and Evaluate (ME). Domain PO merupakan strategi dan taktik, serta perhatian pada identifikasi TI dalam memberikan kontribusi pada pencapaian objektif. Domain AI merupakan realisasi, implementasi, dan integrasi strategi $\mathrm{TI}$ di dalam proses bisnis. Domain DS merupakan penyampaian dan dukungan layanan TI. Domain ME merupakan pengawasan pada seluruh kendali yang diterapkan pada setiap proses TI.

Domain yang dipakai dari COBIT 4.1 untuk melakukan evaluasi tata kelola TI di Diskominfo Kabupaten Labura adalah Domain Monitor and Evaluate $(M E)$. Solusi yang didapatkan setelah melakukan evaluasi tata kelola TI pada Diskominfo kabupaten Labura adalah pihak instansi dapat mengetahui sejauh mana tingkat maturity level yang sekarang sedang berjalan, serta dapat meningkatkan maturity level setelah dilakukan evaluasi tata kelola TI.

Domain Monitor and Evaluate
Pada tahap ini, peneliti menentukan proses yang tepat dengan standar COBIT 4.1 dan telah diolah sesuai dengan studi kasus, maka proses domain yang ingin diukur adalah sebagai berikut (Rahayu, 2020) :

\section{ME 1 (Monitor the Process)}

Tahap ini untuk mengetahui instansi sadar akan kebutuhan proses pengawasan. Proses pengawasan apakah sesuai dengan standar operasional prosedur (SOP) yang berlaku, termasuk dalam mendefinisikan peforma pengendalian yang relevan, sistematik, dan sebuah laporan yang dilakukan secara berkala serta penanganan yang cepat dan efektif saat terjadi masalah.

2. ME 2 (Assess Internal Control Adequacy)

Tahap ini untuk menentukan pengendalian internal pada instansi tergambarkan dengan baik dan efisien untuk TI. Fungsi utama dari pemantauan pengendalian internal ini memberikan jaminan mengenai jalannya sistem yang efektif, efisien dan ketaatan terhadap hukum dan peraturan yang berlaku.

3. $\mathrm{ME} 3$ (Obtain Independent Assurance)

Tahap ini menentukan ketaatan hukum dan peraturan kontrak. Tahap ini juga mengidentifikasi persyaratan kepatuhan, memaksimalkan dan mendapat jaminan bahwa persyaratan telah dipenuhi sehingga antara peraturan dan tujuan bisnis terintergrasi dengan baik.

4. ME 4 (Provide IT Governance)

Tahap ini menetapkan kerangka kerja tata kelola yang efektif mencakup menentukan struktur organisasi, proses, kepemimpinan, peran dan tanggungjawab untuk memastikan bahwa investasi TI instansi selaras dengan strategi dan tujuan instansi.

\section{Maturity Level}

Tingkat kematangan menjadi parameter dalam standar COBIT dimana maturity level yang digunakan untuk 
Available online at http://jurnal.goretanpena.com/index.php/JSSR

menentukan sejauh mana tingkat proses dan pengelolaan TI didalam sebuah instansi (Rajasa dan Faturachman, 2015; Sukmajaya dan Andry, 2017). Dalam jurnal Alkhaldi bahwa maturity level adalah suatu standar kompetensi yang penting dalam peningkatan kinerja, yang membantu dalam mengukur bagaimana proses bertemu dengan situasi bisnis dan tujuan teknologi informasi (Alkhaldi, 2017).

Berikut ini adalah penjelasan mengenai maturity level yang dipakai :

\section{Level 0 (Non-existent)}

Bahwa di dalam instansi tidak memiliki kesadaran akan perkembangan TI dalam mencapai tujuan instansi.

\section{Level 1 ( Initial)}

Bahwa sudah ada solusi teknologi dalam instansi tetapi belum ada standarisasi atau stuktur yang jelas.

\section{Level 2 (Repeatable but Intuitive)}

Bahwa instansi sudah dalam mengembangkan proses yang ada. Namun belum adanya pelatihan dan kemampuan dalam penggunaanya.

\section{Level 3 ( Defined Process)}

Bahwa suatu instansi sudah memiliki prosedur yang sesuai standar yang ada dan sudah terstuktur. Proses ini sudah di tangani oleh instansi meskipun belum seimbang dengan prosedur yang sudah ditetapkan.

\section{Level 4 (Managed and Measurable )}

Bahwa instansi telah mengawasi dalam pemenuhan solusi TI dan sudah berjalan seimbang dengan prosedur. Solusi yang sudah ada berjalan dengan baik dan dapat dikembangkan lagi untuk kedepannya.

\section{Level 5 (Optimized)}

Bahwa instansi sudah mencapai level tertinggi atau level yang sangat baik dibanding level sebelumnya dalam penggunaan TI. Bahkan instansi sudah mampu dalam memanfaatkan teknologi menjadi sebuah strategi bisnis.

\section{Rumus Cobit 4.1}

Rumus COBIT 4.1 dapat digambarkan secara matematis sebagai berikut : Maturity Level : $\sum$ Nilai Pertanyaan

\section{$\sum$ Pertanyaan $* \sum$ Koresponden}

Keterangan :

1. $\sum$ Pertanyaan $=$ Menunjukan jumlah dari banyaknya pertanyaan.

2. $\sum$ Koresponden $=$ Menunjukan jumlah dari banyaknya koresponden.

3. $\sum$ Nilai Pertanyaan $=$ Menunjukan jumlah total dari nilai - nilai. pertanyaan yang didapat dari range $0-5$.

4. $0-5$ menunjukan level dari tingkat kematangan.

\section{METODE}

Metode yang digunakan dalam penelitian ini meliputi metode kualitatif deskriptif.

Pada metode ini data yang ada dikumpulkan, disusun, dikelompokkan dan dianalisis sehingga diperoleh beberapa gambaran yang jelas pada masalah yang akan dibahas. Sementara pengumpulan data dilakukan dengan metode-metode sebagai berikut :

1. Observasi, metode pengumpulan data melalui pendekatan ke lapangan dengan mengambil data-data yang ada di lapangan atau melakukan peninjauan secara langsung ke objek yang diteliti.

2. Wawancara (Interview), sejalan dengan observasi penulis melakukan wawancara kepada pihak Diskominfo Labura, mulai dari kepala dinas, beberapa kabag dan juga para staff.

3. Dokumen, penulis mengumpulkan berupa dokumen-dokumen yang diperlukan dari tempat-tempat riset terkait yang digunakan untuk keperluan penelitian. 
Available online at http://jurnal.goretanpena.com/index.php/JSSR

4.Kuesioner, penulis memberikan kuesiner kepada kepala dinas, kabag dan juga para staff di Diskominfo Labura tersebut.

5. Pemilihan Kerangka Kerja (Framework ), Pemilihan kerangka kerja dipilih agar penelitian terstruktur. Terdapat banyak framework yang bisa digunakan dalam penelitian ini seperti ISO 3000, ITIL, COBIT 4.1, dan COBIT 5. Tetapi peneliti menentukan untuk menggunakan COBIT 4.1.

6.Pemilihan Domain, Setelah menentukan framework COBIT 4.1 pada penelitian ini, lalu menentukan domain yaitu dalam penelitian ini domain yang digunakan adalah monitor and evaluate (ME).

7.Analisis Tingkat Kematangan, Menganalisis tingkat kematangan data berdasarkan hasil dari wawancara dan observasi yang sudah dilakukan.

8. Kesimpulan dan Saran, Selanjutnya memberikan saran kepada instansi untuk perbaikan sesuai hasil akhir dari maturity level yang diharapkan untuk masa yang akan datang.

\section{HASIL DAN PEMBAHASAN}

Untuk melakukan audit dengan pendekatan Cobit 4.1 pada domain ME maka dilakukan penyebaran kuesioner kepada seluruh jajaran Diskominfo Labura yang skor jawabannya seperti tabel skor jawaban ME1 :

\begin{tabular}{|c|l|c|}
\hline No & \multicolumn{1}{|c|}{ Deskripsi } & Skor \\
\hline 1 & Tidak ada & 0 \\
\hline 2 & Ada, belum dilakukan & 1 \\
\hline 3 & $\begin{array}{l}\text { Ada, sedikit dilakukan, } \\
\text { tidak ada prosedur }\end{array}$ & 2 \\
\hline 4 & $\begin{array}{l}\text { Ada, sudah dilakukan, } \\
\text { tidak ada prosedur }\end{array}$ & 3 \\
\hline 5 & $\begin{array}{l}\text { Ada, sudah dilakukan, } \\
\text { ada prosedur }\end{array}$ & 4 \\
\hline 6 & $\begin{array}{l}\text { Dilakukan dengan baik, } \\
\text { ada prosedur, ada } \\
\text { pengawasan }\end{array}$ & 5 \\
\hline
\end{tabular}

Untuk tabel skor jawaban ME2-ME4 :

\begin{tabular}{|c|l|c|}
\hline No & \multicolumn{1}{|c|}{ Deskripsi } & Skor \\
\hline 1 & Kurang Sekali & 0 \\
\hline 2 & Kurang & 1 \\
\hline 3 & Cukup & 2 \\
\hline 4 & Lebih dari cukup & 3 \\
\hline 5 & Baik & 4 \\
\hline 6 & Baik Sekali & 5 \\
\hline
\end{tabular}

Sehingga didapatlah rekapitulasi data koresponden di Diskominfo Labura :

\begin{tabular}{|c|c|c|c|c|c|}
\hline $\begin{array}{c}\text { Respon } \\
\text { den }\end{array}$ & $\begin{array}{c}\text { ME } \\
\mathbf{1}\end{array}$ & $\begin{array}{c}\text { ME } \\
\mathbf{2}\end{array}$ & $\begin{array}{c}\text { ME } \\
\text { ME }\end{array}$ & $\begin{array}{c}\text { Tot } \\
\text { al }\end{array}$ \\
\hline R2 & 23 & 21 & 12 & 19 & 75 \\
\hline R3 & 24 & 21 & 12 & 18 & 73 \\
\hline R4 & 23 & 20 & 12 & 18 & 71 \\
\hline R5 & 23 & 22 & 11 & 18 & 74 \\
\hline R6 & 23 & 18 & 11 & 18 & 74 \\
\hline R7 & 22 & 21 & 13 & 20 & 76 \\
\hline R8 & 23 & 21 & 12 & 18 & 74 \\
\hline R9 & 23 & 21 & 11 & 18 & 73 \\
\hline R10 & 22 & 22 & 12 & 19 & 75 \\
\hline R11 & 22 & 21 & 12 & 19 & 75 \\
\hline R12 & 24 & 20 & 11 & 18 & 73 \\
\hline R13 & 23 & 21 & 12 & 20 & 76 \\
\hline R14 & 22 & 22 & 13 & 20 & 77 \\
\hline R15 & 22 & 20 & 12 & 20 & 74 \\
\hline R16 & 23 & 21 & 12 & 18 & 74 \\
\hline R17 & 22 & 20 & 11 & 19 & 72 \\
\hline R18 & 24 & 20 & 12 & 20 & 76 \\
\hline R19 & 23 & 19 & 12 & 21 & 76 \\
\hline R20 & 22 & 21 & 12 & 21 & 76 \\
\hline Total & $\mathbf{4 5 7}$ & $\mathbf{4 1 3}$ & $\mathbf{2 3 7}$ & $\mathbf{3 8 0}$ & $\mathbf{1 4 8}$ \\
\hline
\end{tabular}

\begin{tabular}{|l|l|}
\hline $\begin{aligned} \text { ME } 1 & =457 / 8 * 20 \\
& =457 / 520 \\
& =2.9\end{aligned}$ & $\begin{array}{r}\text { ME } 2=413 / 7 * 20 \\
=415 / 140 \\
=2.95\end{array}$ \\
Skala $=3$ & Skala $=3$ \\
&
\end{tabular}


Available online at http://jurnal.goretanpena.com/index.php/JSSR

Berikut perbandingan nilai GAP dari hasil kuisioner yang telah diisi oleh responden :

\begin{tabular}{|c|c|c|c|}
\hline $\begin{array}{c}\text { Domai } \\
\text { n }\end{array}$ & $\begin{array}{c}\text { Level } \\
\text { Sekarang }\end{array}$ & Harapan & GAP \\
\hline ME 1 & 2,86 & 4 & 1,14 \\
\hline ME 2 & 2,95 & 4 & 1,05 \\
\hline ME 3 & 2,37 & 4 & 1,63 \\
\hline ME 4 & 3,17 & 4 & 0,83 \\
\hline $\begin{array}{c}\text { Rata - } \\
\text { rata }\end{array}$ & $\mathbf{2 , 8 4}$ & $\mathbf{4}$ & $\mathbf{1 , 1 6}$ \\
\hline
\end{tabular}

Setelah melaui proses perancangan dan implementasi dari datadata yang diperoleh melalui pengumpulan data sebelumnya dihasilkan sebuah aplikasi audit Diskominfo Labura yang menggunakan bahasa PHP dan MySql. Adapun tampilan dari aplikasi tersebut dapat dilihat pada gambar berikut.

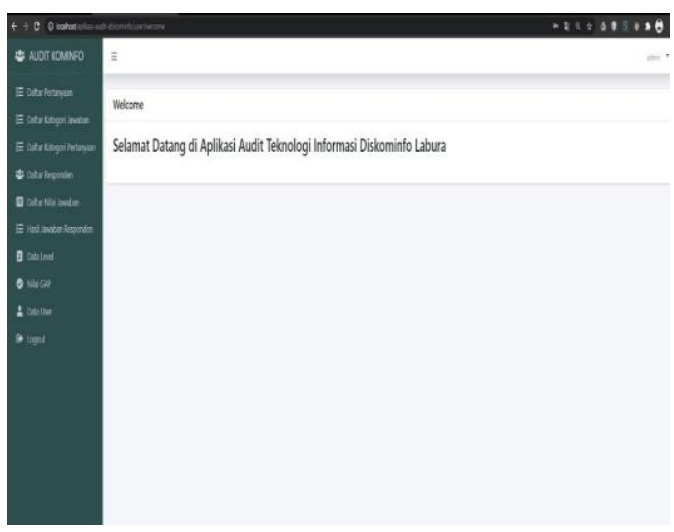

\section{Gambar Halaman Utama}

Pada gambar tersebut memuat tentang daftar pertanyaan, daftar kategori pertanyaan, daftar kategori jawaban, daftar responden, daftar nilai responden, hasil jawaban responden, data level dan nilai GAP.

Ketika responden login berdasarkan user masing-masing dengan memberi nilai pada setiap pertanyaan maka sistem dengan cepat akan memberikan hasil kalkulasi dari setiap nilai pertanyaan tersebut seperti tampilan berikut :

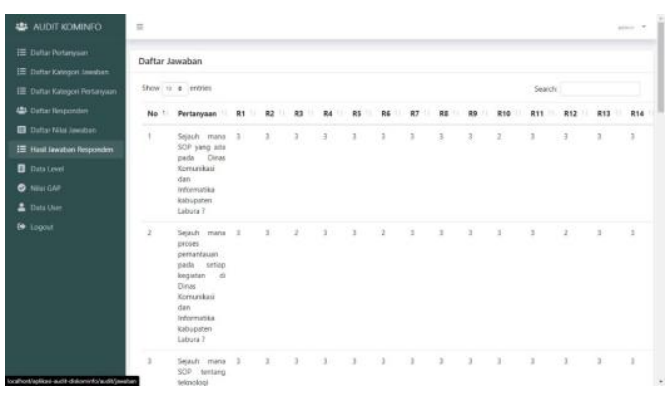

\section{Gambar Hasil Responden}

Dari hasil jawaban responden tersbut maka tentu didapat level dari tingkat monitor dan evaluasi yang diterapkan di Diskominfo Labura seperti tampilan di bawah ini :

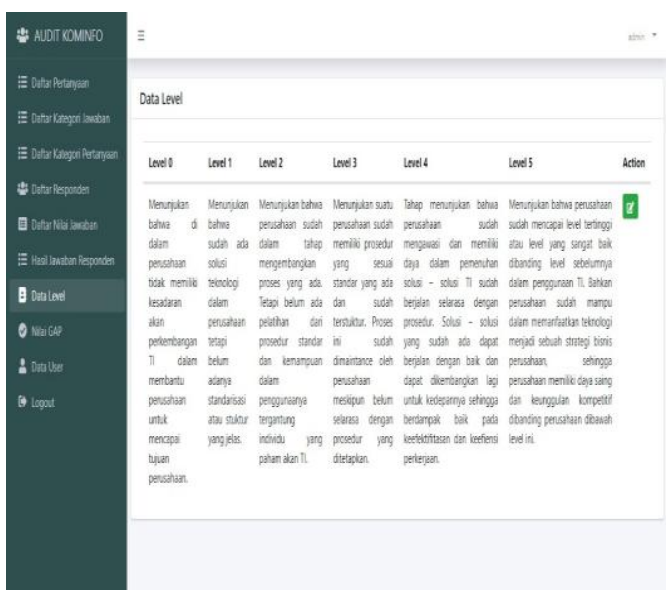

\section{Gambar Level}

Dari hasil yang didapat diketahui bahwa maturity level dari sistem pengelolahan tata kelola teknologi informasi berada pada level 2,84 sedangkan target yang ingin dicapai adalah level 4. Dari perbandingan tersebut dapat diperoleh GAP sebesar 1,16, Dinas Kominfo Labura saat ini berapa pada level 3 yaitu Defeined Process. $\mathrm{Hal}$ ini menunjukan bahwa belum tercapainya target maturity level seperti yang diharapkan Diskominfo kabupaten Labura. Untuk meningkatkan pencapaian kinerja sistem informasi ini maka peneliti memaparkan beberapa rekomendasi perbaikan sesuai dengan skala prioritas yang telah ditetapkan. 
Available online at http://jurnal.goretanpena.com/index.php/JSSR

Tentu didapatlah nilai GAP seperti di bawah ini :

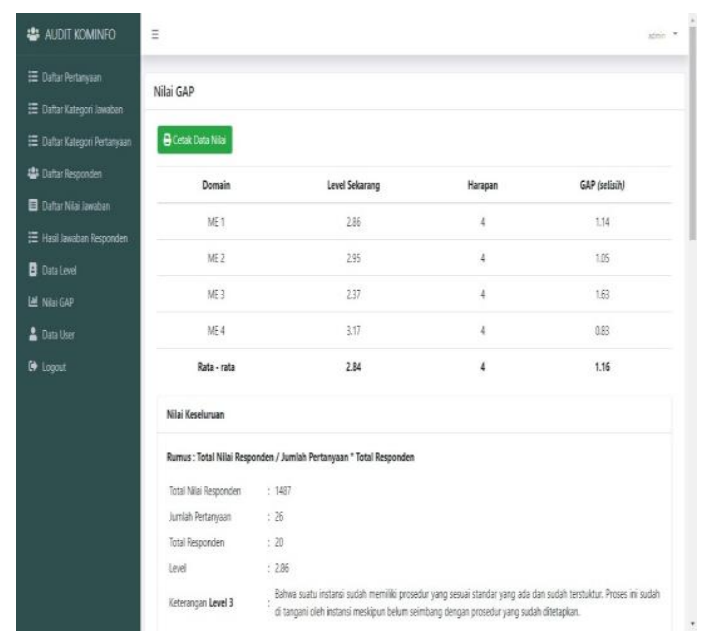

\section{Gambar Tampilan Nilai GAP}

Juga dapat ditampilkan GAP tersebut dalam bentu grafik seperti di bawah ini :

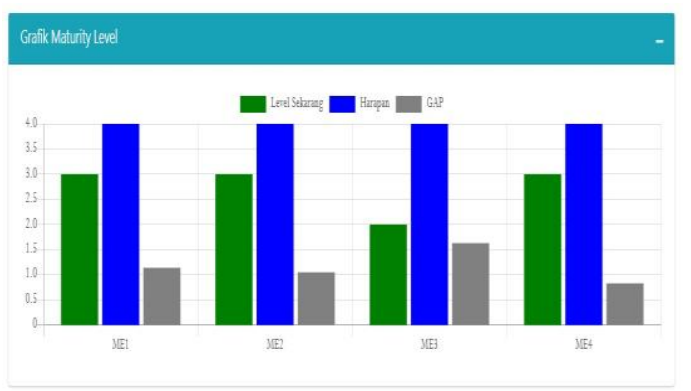

Gambar Grafik Level

\section{SIMPULAN}

1. Saat ini Dinas Komunikasi dan Informatika kabupaten Labura telah menginplementasikan framework evaluasi dan pengawasan pada tingkat defined process. Tingkat tersebut didapatkan berdasarkan hasil wawancara dari beberapa standar domain yaitu ME1, ME2, ME3, dan ME4 yang telah diolah dengan menghasilkan rata-rata nilai maturity level sebesar 2,84 dengan harapan level 4 dan memiliki gap sebanyak 1,16 .
2. Berdasarkan hasil perhitungan maturity level, diketahui bahwa nilai subdomain yang paling tertinggi terdapat pada domain ME1 dengan nilai 2,8 yang termasuk dalam level defined process. Sedangkan, nilai subdomain yang paling terendah terdapat pada ME3 sebesar 2,37 yang masih termasuk pada level Repeatabel but Intuitive.

3. Evaluasi tata kelola TI ini mampu meminimalisir kesalahan yang biasa dilakukan manusia (human error) dalam perhitungan.

\section{DAFTAR PUSTAKA}

Rahayu, a. S., \& wijaya, a. F. (2020). Evaluasi kinerja teknologi informasi berdasarkan domain monitor and evaluate menggunakan cobit 4.1 (studi kasus: pt. Global infotech solution). Jurnal bina komputer, 2(1), 44-51.

Andry, J. F., Geasela, Y. M., Wailan, A., Matjik, B. A., Kurniawan, A., \& Junior, J. (2019). Penggunaan COBIT 4.1 Dengan Domain ME Pada Sistem Informasi Absensi (Studi Kasus: Universitas XYZ). Inform. Mulawarman $J$. Ilm. Ilmu Komput, 13(2), 97.

Pambudi, R., \& Suprapto, Y. T. M. (2018). Evaluasi Tata Kelola Teknologi Informasi Pada Dinas Komunikasi dan Informatika (DISKOMINFO) Kota Probolinggo Menggunakan Framework COBIT 4.1 Domain Deliver and Support (DS) dan Monitor and Evaluate (ME). Jurnal Pengembangan Teknologi Informasi dan Ilmu Komputer e-ISSN, 2548, 964X.

Lesmono, I. D., \& Erica, D. (2018). Tata Kelola Teknologi Informasi Dengan Metode COBIT 4.1 (Studi Kasus: PT. IMI). Jurnal Kajian Ilmiah, 18(1), 75-84 
Available online at http://jurnal.goretanpena.com/index.php/JSSR

Kurniawan, R., Yohanes, A., Wijaya, A., Fernaldy, F., William, W., \& Andry, J. F. (2018). Audit Aplikasi Medico Menggunakan Framework COBIT 4.1 Domain ME. Jurnal Teknoinfo, 12(2), 3842.

Alkhaldi, F. M., Hammami, S. M., \& Ahmar Uddin, M. (2017). Understanding value characteristics toward a robust IT governance application in private organizations using COBIT framework. International Journal of Engineering Business Management, 9,

Aprianti, W., \& Maliha, U. (2017). Sistem Informasi Kepadatan Penduduk Kelurahan Atau Desa Studi Kasus Pada Kecamatan Bati-Bati Kabupaten Tanah Laut. Jurnal Sains dan Informatika, 2(1).

Destiningrum, M., \& Adrian, Q. J. (2017). Sistem Informasi Penjadwalan Dokter Berbassis Web Dengan Menggunakan Framework Codeigniter (Studi Kasus: Rumah Sakit Yukum Medical Centre). Jurnal Teknoinfo, 11(2), 30-37.

Jelvino, \& Andry, J. F. (2017). Audit Sistem Informasi Absensi pada PT . Bank Central Asia Tbk menggunakan COBIT 4 . 1. Jurnal Teknik Informatika Dan Sistem Informasi, 3(2), 259- 268.

Sukmajaya, I. B., \& Andry, J. F. (2017, November). Audit Sistem Informasi Pada Aplikasi Accurate Menggunakan Model Cobit Framework 4.1 (Studi Kasus: Pt. Setia Jaya Teknologi).
In Prosiding Seminar Nasional Teknoka (Vol. 2, pp. I42-I51).

Winalia, W., Renaldi, F., \& Hadiana, A. I. (2017, August). Pengukuran Tingkat Kematangan Teknologi Informasi menggunakan COBIT 4.1 Pada Universitas Jenderal Achmad Yani. In Seminar Nasional Aplikasi Teknologi Informasi (SNATI).

Andry, J. F. (2016). Audit Tata Kelola Ti Menggunakan Kerangka Kerja Cobit Pada Domain DS Dan ME Di Perusahaan Kreavi Informatika Solusindo. Sentika, 5(2), 287-294 